\title{
IMMUNOLOGICAL CONTROL OF FERTILITY IN THE MOUSE: \\ A COMPARISON OF SYSTEMIC AND INTRAVAGINAL IMMUNIZATION
}

\author{
ERIG B. BELL* \\ Institute of Animal Genetics, Edinburgh
}

(Received 29th February 1968)

\begin{abstract}
Summary. Systemic iso-immunization of the random bred $Q$ strain of mice with spermatozoa resulted in a significant reduction $(P<0 \cdot 001)$ of litter size. Re-immunization depressed fertility further to less than half the control level. Serum antibody levels were assayed both by a passive haemagglutination test adapted for detecting antibodies against mouse spermatozoa, and by a sperm-agglutination test. There was a significant regression of numbers of offspring on both sperm-agglutination and haemagglutination titres.

Intravaginal iso-immunization with mouse spermatozoa failed to alter the fecundity in short-term breeding periods or during long-term mating or to enhance the sterility induced by systemic injections.
\end{abstract}

\section{INTRODUCTION}

Efforts to control fertility in the female by immunization with spermatozoa has a history starting shortly after the turn of the century (Savini \& SaviniCastano, 1911). However, the earlier reports of success came under question by Henle \& Henle (1940) and Parson \& Hyde (1940) who failed to find any immunological suppression of fertility in more carefully controlled experiments. It was clear from reviews by Katsh (1959a) and Tyler (1961) and aptly expressed by Tyler \& Bishop (1963) that "The earlier work ... was beset by variations in procedure, uncontrolled experiments, false claims and over enthusiasm."

Previous experiments on control of fertility in the mouse have not been in complete agreement. Henle, Henle, Ghurch \& Foster (1940) failed to suppress fertility by passive immunization of the female mouse. However, McLaren (1964) reported a marked depression of fertility after active immunization with mouse spermatozoa and a close association between the sperm-agglutination titre of the serum and a reduction of litter size. Edwards (1964), using a different immunizing procedure, found a significantly smaller effect on fertility with no relationship between fertilization rate and serum titre.

The effectiveness of fertility suppression and the degree of immunological

* Present address: Department of Zoology, University of Edinburgh, Edinburgh. 
response can be greatly influenced by the frequency of injection (Snell \& Poucher, 1943), the source of the antigen (Edwards, 1960a; Henle, Henle \& Chambers, 1938; Menge \& Protzman, 1967; Weil, 1960; Weil \& Roberts, 1965; Willson \& Katsh, 1965), and the route of injection. The intravaginal route of immunization deserves consideration since as a natural phenomenon the vagina becomes exposed to a large quantity of homologous antigen (spermatozoa) regularly during a life-span. Several workers have demonstrated transvaginal sensitization to heterologous spermatozoa (Edwards, 1960b; Parson \& Hyde, 1940) and there were claims that vaginal absorption of homologous spermatozoa would induce an antibody response as well as cause a reduction of fertility (Behrman \& Otani, 1963; McCartney, 1923; Otani, Behrman, Porter \& Nakayama, 1963; Pommerenke, 1928). Local antibody production by the vagina might also have a significant role after intravaginal immunization, since Bell \& Wolf (1967) demonstrated synthesis of antibody in vitro by the rabbit vagina.

The present report has investigated induced infertility by the intravaginal route as compared with the systemic method of immunization with homologous spermatozoa. The degree to which fertility control could be assessed by serum antibody levels was also examined.

\section{MATERIALS AND METHODS}

\section{Immunization of mice}

Seven to ten-week-old mice of the highly fertile random bred $Q$ strain were subjected to one of the following schedules of immunization. Group $S$ received intraperitoneal injections of spermatozoa. Group SV was immunized systemically by intraperitoneal injections of spermatozoa and additionally received intravaginal sperm-soaked cotton pellets. Group V received only intravaginal cotton pellets soaked with a suspension of spermatozoa. A control group (CC) was injected intraperitoneally with saline and received saline-soaked pellets intravaginally.

Spermatozoa for immunization were collected in $\mathrm{pH} 7 \cdot 2$ phosphate-buffered saline from the vas deferens and epididymis of $Q$ males and injected within half an hour of collection. About $36 \times 10^{6}$ spermatozoa could be obtained from a single male. Females were injected intraperitoneally with approximately $6 \times 10^{6}$ spermatozoa in $0.1 \mathrm{ml}$ and the intravaginal cotton pellets contained approximately $20 \times 10^{6}$ spermatozoa.

Mice were immunized three times a week on alternate days for 8 weeks. Ten days later a blood sample was collected from the orbital anastomosis and the female paired with a fertile $Q$ male for 37 days-sufficient time for no more than two litters. After an additional 3 weeks the females underwent a re-immunization at half the original level, i.e. 3 times/week, for 4 weeks (twelve injections). Similarly, blood samples were taken 10 days following the last injection, males were provided and breeding permitted for 4 months. A check for copulation plugs after pairing assured that mating was taking place. Pregnant females were checked daily for births, litter size recorded and the offspring removed on the day of birth. 
Immunological assays

Blood samples were allowed to clot, the serum drawn off, diluted 1:1 with

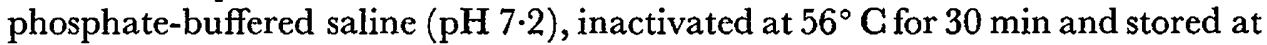
$-20^{\circ} \mathrm{C}$.

The procedure for titration of sperm-agglutinins, as described by McLaren (1964), was employed. $0.05 \mathrm{ml}$ of a freshly collected suspension of mouse spermatozoa (approximately $5 \times 10^{6} / \mathrm{ml}$ ) was added to $0.05 \mathrm{ml}$ of a two-fold serial dilution of serum and examined microscopically 20 to 30 min later at room temperature for agglutination. The end point of the reaction was determined by the standard method after criteria set down by Smith (1949). Boyden's (1951) passive haemagglutination test as modified by Stavitsky was adapted in this laboratory for detecting anti-mouse spermatozoa antibodies. Tannic acid-treated fresh sheep red blood cells were coated with a 'solubilized' preparation of mouse spermatozoa. 'Solubilized' spermatozoa were produced by forcing a suspension of spermatozoa in phosphate buffered saline $\left(5 \times 10^{7}\right.$ spermatozoa $/ \mathrm{ml}$ ) twice through a Ribi cell fractionator first at $20,000 \mathrm{lb} / \mathrm{sq}$. in. and then at $30,000 \mathrm{lb} / \mathrm{sq}$. in. After centrifugation, the supernatant was dialysed overnight at $4^{\circ} \mathrm{G}$ against $\mathrm{pH} 7.2$ phosphate buffered saline and used for coating within 3 days or stored at $-20^{\circ} \mathrm{G}$. In each titration, specificity of the titre was confirmed by simultaneous haemagglutination-inhibition tests with the same soluble antigen and the use of tannic acid-treated sheep erythrocytes that had not been coated with antigen.

\section{RESULTS}

Litter sizes in groups S, V, SV and CG (systemically, intravaginally, systemically plus intravaginally and saline-injected controls, respectively) were normally distributed. Mean numbers of offspring per female were compared. An analysis

TABLE 1

ANALYSIS OF VARIANCE OF THE MEAN NUMBER OF OFFSPRING PER FEMALE BETWEEN IMMUNIZED GROUPS S, SV AND V AND CONTROL GROUP CG

\begin{tabular}{|c|c|c|c|c|}
\hline & $d . f$. & $\begin{array}{l}\text { Mean } \\
\text { square }\end{array}$ & $F$ & $\mathbf{P}$ \\
\hline $\begin{array}{l}\text { First litter } \\
\text { Between } \\
\text { Within }\end{array}$ & $\begin{array}{r}3 \\
143\end{array}$ & $\begin{array}{r}109.35 \\
11.50\end{array}$ & $9 \cdot 51$ & $<0.001$ \\
\hline $\begin{array}{l}\text { First }+ \text { second litter } \\
\text { Between } \\
\text { Within }\end{array}$ & $\begin{array}{r}3 \\
129\end{array}$ & $\begin{array}{r}375.00 \\
\mathbf{3 5 . 9 7}\end{array}$ & 10.43 & $<0.001$ \\
\hline $\begin{array}{l}\text { Re-immunization third litter } \\
\text { Between } \\
\text { Within }\end{array}$ & $\begin{array}{r}3 \\
115\end{array}$ & $\begin{array}{r}142.67 \\
12.44\end{array}$ & $11 \cdot 47$ & $<0.001$ \\
\hline $\begin{array}{l}\text { Third }+ \text { fourth litter } \\
\text { Between } \\
\text { Within }\end{array}$ & $\begin{array}{r}3 \\
115\end{array}$ & $\begin{array}{r}307.33 \\
35.55\end{array}$ & $8 \cdot 64$ & $<0.001$ \\
\hline $\begin{array}{l}6 \text { months' totals } \\
\text { Between } \\
\text { Within }\end{array}$ & $\begin{array}{r}3 \\
112\end{array}$ & $\begin{array}{c}980 \cdot 33 \\
158 \cdot 32\end{array}$ & $6 \cdot 19$ & $<0.001$ \\
\hline
\end{tabular}


of variance indicated that there were significant differences between means (Table 1) of the four groups of mice. Systemic immunization (Group S) resulted in a significant reduction of litter size (Table 2). Intravaginal immunization, however, had no significant effect alone (Group V versus CC) or combined with systemic immunization (Group SV versus S).

\section{TABLE 2}

COMPARISON OF MEAN NUMBER OF OFFSPRING PER FEMALE DURING THE FIRST BREEDING PERIOD FROM MICE IMMUNIZED INTRAVAGINALLY (GROUP V), SYSTEMICALLY (GROUP s), INTRAVAgINALly PLUS SYSTEMically (GROUP SV), OR With SALINE CONTROLS (GROUP GC)

\begin{tabular}{|c|c|c|c|c|}
\hline Litter & Group V & Group $C C$ & Group SV & Group $S$ \\
\hline $\begin{array}{l}\text { First } \\
\text { No. of 우 } \\
\text { Mean } \pm \text { S.E. }\end{array}$ & $\begin{array}{c}40 \\
9.92 \pm 0.53\end{array}$ & $\begin{array}{c}48 \\
10 \cdot 54 \pm 0 \cdot 46\end{array}$ & $\begin{array}{c}34 \\
7.41 \pm 0 \cdot 69 \\
* * *\end{array}$ & $\begin{array}{c}25 \\
7 \cdot 80 \pm 0 \cdot 61^{* * *}\end{array}$ \\
\hline $\begin{array}{l}\text { First + second } \\
\text { No. of } q 9 \\
\text { Mean } \pm \text { S.E. }\end{array}$ & $\begin{array}{c}28 \\
18 \cdot 89 \pm 1 \cdot 19\end{array}$ & $\begin{array}{c}47 \\
18 \cdot 19 \pm 0 \cdot 76\end{array}$ & $12 \cdot 18 \pm 1 \cdot 19+* *+$ & $\begin{array}{c}25 \\
13 \cdot 28 \pm 1 \cdot 16^{* * *}\end{array}$ \\
\hline
\end{tabular}

$$
\begin{array}{rl}
\text { Comparisons with: } & \text { controls } \\
\text { Group } V & * * P<0.001 \\
++P<0.01 & +++P<0.001
\end{array}
$$

Although the mean litter size of the entire population declined (as reflected in the controls) after a period of re-immunization, the pattern of immunological depression was the same (Table 3). Whereas the first course of injections resulted in a decrease in mean number of offspring by about $26 \%$ after the

\section{TABLE 3}

COMPARISON OF MEAN NUMBER OF OFFSPRING PER FEMALE BETWEEN GROUPS V, S, SV AND CC AFTER RE-IMMUNIZATION, AND AFTER A TOTAL OF 6 MONTHS' EXPOSURE WITH MALES

\begin{tabular}{|c|c|c|c|c|}
\hline Litters & Group V & Group CC & Group SV & Group $S$ \\
\hline $\begin{array}{l}\text { Re-immunization, third } \\
\text { No. of } Q+ \\
\text { Mean } \pm \text { S.E. }\end{array}$ & $\begin{array}{c}30 \\
8.03 \pm 0.65\end{array}$ & $\begin{array}{c}36 \\
8 \cdot 17 \pm 0 \cdot 61\end{array}$ & $\begin{array}{c}30 \\
3.93 \pm 0.66+* *+\end{array}$ & $\begin{array}{c}23 \\
4 \cdot 87 \pm 0 \cdot 64 * * *\end{array}$ \\
\hline $\begin{array}{l}\text { Third + fourth } \\
\text { No. of } \$ 9 \\
\text { Mean } \pm \text { S.E. }\end{array}$ & $\begin{array}{c}30 \\
13.27 \pm 1.04\end{array}$ & $\begin{array}{c}36 \\
13 \cdot 44 \pm 0.99\end{array}$ & $\stackrel{30}{7 \cdot 33 \pm 1 \cdot 21+++}$ & $\begin{array}{c}23 \\
8 \cdot 43 \pm 1 \cdot 14 * *\end{array}$ \\
\hline $\begin{array}{l}6 \text { months' totals } \\
\text { No. of } \varphi q \\
\text { Mean } \pm \text { S.E. }\end{array}$ & $\begin{array}{c}28 \\
35 \cdot 61 \pm 2 \cdot 28\end{array}$ & $\begin{array}{c}36 \\
35.55 \pm 1.68\end{array}$ & $\frac{30}{24 \cdot 33 \pm 2 \cdot 74++*}$ & $\begin{array}{c}22 \\
27 \cdot 50 \pm 2 \cdot 88^{*}\end{array}$ \\
\hline
\end{tabular}

first litter, the re-immunization procedure depressed the litter size by $52 \%$ in the third litter.

Reduction of fertility after a total of 6 months' exposure to a male was again realized only in Groups S and SV (Table 3), indicating that systemic immunization was necessary to depress fecundity. 
Serum samples collected on the day of pairing were assayed for spermagglutination and passive haemagglutination antibody. Serum titres from vaginally immunized mice (Group $\mathrm{V}$ ) gave no indication of an immune response. In Group V, sperm-agglutination titres ranged from $<1: 8$ to 1:64, but only rarely did a titre exceed 1:16. Titres from the control mice showed a similar distribution. A majority of the haemagglutination titres from vaginally immunized mice did not exceed $1: 9$, although three mice consistently gave

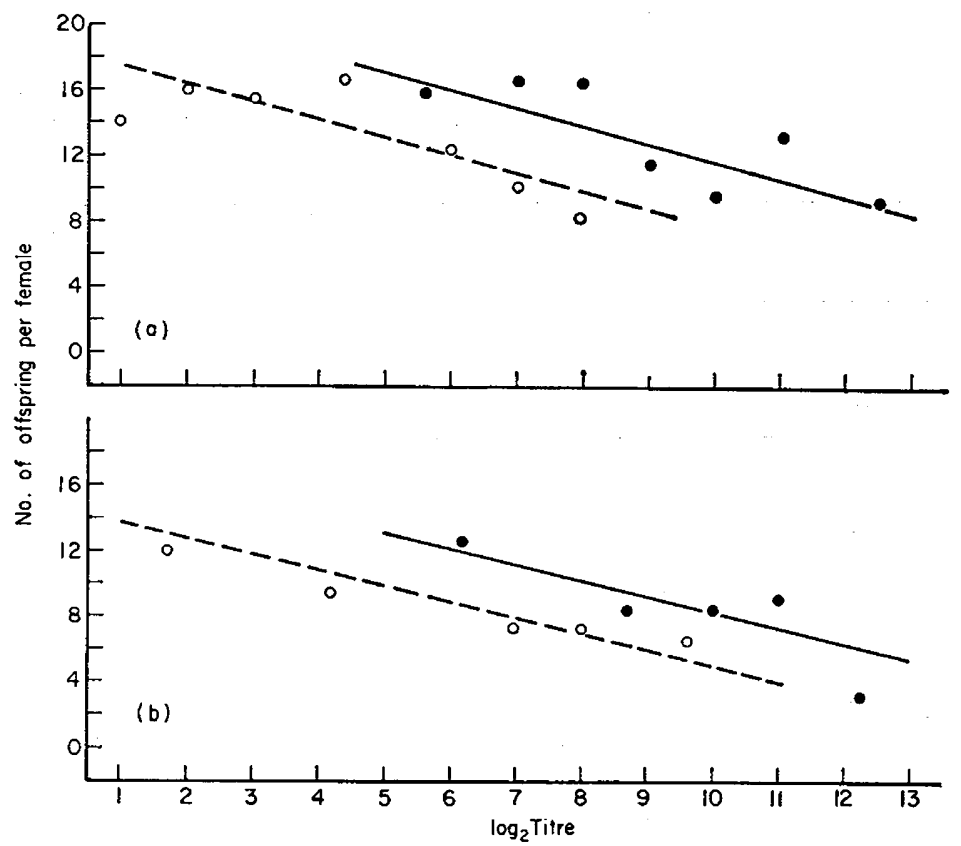

TexT-pig. 1. Regression of the number of new-born per female on sperm-agglutination and haemagglutination titre in systemically immunized mice after the first immunization period (a) and after re-immunization (b). Each point represents the mean of three to seventeen mice. The pairs of regression lines have been fitted, using a common slope. $\longrightarrow, \mathrm{Sp}-\mathrm{Ag}$ titration $(\bullet)$; serum diluted $1: 2$ before titration. - . ....., HA titration $(0)$; serum diluted $1: 2 \cdot 25$ before titration.

titres between $1: 36$ and $1: 144$. Two control mice also had titres $>1: 36$; however, it was unusual for a titre to exceed 1:9 in the control group.

Since no difference in titres could be detected between Groups S and SV, and since intravaginal immunization alone did not induce a detectable response, these two groups were combined and considered as a single set of systemically immunized mice for all succeeding statistical analyses.

Systemic immunization produced a varied response. Titres ranged from 1:16 to $1: 8192$ for sperm-agglutinins and from $<1: 9$ to $1: 9216$ with the passive haemagglutination test. There was a significant correlation between spermagglutination titre and haemagglutination titre for both the first immunization period $(P<0.01$, correlation coefficient $r=0.407)$ and after re-immunization $(P<0.001, \mathrm{r}=0.577)$.

A regression analysis of litter size on titre indicated that fertility was 
significantly depressed with increasing antibody levels (both assays $P<0.01$ ) during the first breeding period (first + second litter) and after re-immunization (Sp-Ag, $P<0.02 ; \mathrm{HA}, P<0.05)$. The regressions did not differ significantly from linearity and the negative regression lines are plotted in the graphs of

TABLE 4

COMPARISON OF THE REGRESSION OF LITTER SIZE ON SPERM-AGGLUTINATION (SP-AG) AND HAEMAGGLUTINATION (HA) TITRES FROM SYSTEMICALLY IMMUNIZED MICE (GROUPS S AND SV)

\begin{tabular}{l|c|c|c|c}
\hline \multirow{2}{*}{ Assay } & \multicolumn{2}{|c|}{ First + second litter } & \multicolumn{2}{|c}{$\begin{array}{c}\text { Re-immunization } \\
\text { third }+ \text { fourth litter }\end{array}$} \\
\cline { 2 - 4 } & $\mathrm{r}$ & $\mathrm{b}$ & $\mathrm{r}$ & $\mathrm{b}$ \\
\hline Sp-Ag & 0.397 & -1.366 & 0.343 & -1.246 \\
$\mathrm{HA}$ & 0.347 & -0.871 & 0.341 & -0.807 \\
\hline
\end{tabular}

\begin{tabular}{|c|c|c|c|c|c|c|}
\hline Source of variation & d.f. & M.S. & $\mathbf{P}$ & d.f. & M.S. & $\mathbf{P}$ \\
\hline $\begin{array}{l}\text { Difference in position } \\
\text { Common slope } \\
\text { Difference in slopes } \\
\text { Residual }\end{array}$ & $\begin{array}{r}1 \\
1 \\
1 \\
109\end{array}$ & $\begin{array}{r}356 \cdot 60 \\
78 \cdot 59 \\
12 \cdot 81 \\
4 \cdot 39\end{array}$ & $\begin{array}{l}\ll 0.001 \\
<0.01 \\
>0.05\end{array}$ & $\begin{array}{r}1 \\
1 \\
1 \\
80\end{array}$ & $\begin{array}{r}281 \cdot 07 \\
56 \cdot 04 \\
2 \cdot 17 \\
4 \cdot 90\end{array}$ & $\begin{array}{l}\ll 0.001 \\
<0.02 \\
>0.5\end{array}$ \\
\hline
\end{tabular}

$\mathbf{r}=$ correlation coefficient, $\mathrm{b}=$ regression coefficient.

Text-fig. 1. Accuracy of the antibody tests in estimating infertility could be evaluated by the correlation and regression coefficients (Table 4). It is apparent that neither assay was significantly superior in this respect. The overall level of titre can be estimated by the position of the regression lines, provided the slopes of the lines being compared do not differ. Since there was no significant

\section{TABLE 5}

COMPARISON OF THE EFFECT OF REIMMUNIZATION ON INCREASING THE SPERM-AGGLUTINATION (SP-AG) AND HAEMAGGLUTINATION (HA) TITRES AMONG SYSTEMICALLY IMMUNIZED MICE

\begin{tabular}{l|c|c|c|c|c|c}
\hline \multirow{4}{*}{ Assay } & \multicolumn{2}{|c|}{ Log $_{2}$ of geometric mean titre \pm S.E. } & \multicolumn{4}{c}{ No. of mice where titre: } \\
\cline { 2 - 7 } & First immunization & Re-immunization & Increased & $\begin{array}{c}\text { Remained } \\
\text { the same }\end{array}$ & Decreased & $\mathrm{P}^{*}$ \\
\hline Sp-Ag & $9.02 \pm 0.25$ & $9.93 \pm 0.26$ & 27 & 8 & 8 & $\begin{array}{r}0.002 \\
<0.001\end{array}$ \\
HA & $4.42 \pm 0.47$ & $6.24 \pm 0.57$ & 26 & 6 & 1 & $<$ \\
\hline
\end{tabular}

* $P$ determined by the Sign test (Dixon \& Mood, 1946).

difference between slopes in either period (Table 4), the marked difference in position $(P \ll 0 \cdot 001)$ indicated that the sperm-agglutination test gave a higher titre for an equivalent level of fertility than the haemagglutination test.

It was of interest to determine whether re-immunization had an appreciable 
influence on increasing the level of antibody in the serum. The before and after re-immunization titres were tested by first removing between female variation. For each female the titre from the first period was paired with its re-immunization titre. Table 5 showed that the re-injection procedure resulted in an elevation of both sperm-agglutination $(P<0.01)$ and haemagglutination $(P<0.001)$ titre. The increased circulating antibody corresponded to a greater percentage reduction of litter size.

\section{DISCUSSION}

Injection of homologous spermatozoa intraperitoneally into the mouse has proven a reliable method for inducing a degree of infertility in this species and confirmed earlier reports by McLaren (1964, 1966) and Edwards (1964). Intravaginal immunization with the same homologous spermatozoa failed to alter the fecundity of the mice or enhance the effect of systemic injections.

Reports of successful intravaginal immunization have been the source of conflicting findings. Thus, Behrman \& Otani (1963) and Otani et al. (1963) claimed to have induced an immune response (in the guinea-pig) and others even to have adversely influenced fertility (Pommerenke, 1928; Behrman \& Nakayama, 1965) following intravaginal injections. Contrary to these findings, Eiseman \& Friedman (1929) failed to confirm Pommerenke's investigation in the rabbit, and Isojima \& Ashitaka (1964) were unable to demonstrate a circulating antibody response in the guinea-pig. In the rabbit, Edwards (1960b) could not evoke an immune response after repeated intravaginal injection of rabbit spermatozoa, although antibody against both egg yolk and bull spermatozoa could be elicited by this procedure. Experiments presented here in the mouse suggested that intravaginal immunization does not affect fecundity. Nor was there any indication that the procedure had stimulated an immune response either locally or by passing into the circulation. It seemed doubtful that a more intensive injection schedule would have been more successful. The cotton pellets containing the antigen remained in the vagina from several hours up to several days.

A report by Franklin \& Dukes (1964) aroused interest in possible absorption of spermatozoa from the reproductive tract after coitus with a resulting natural iso-immunization. They found that a high percentage $(78 \%)$ of women with a history of "unexplained infertility" possessed circulating sperm-agglutinating antibody. More recently Tyler, Tyler \& Denny (1967) investigated this finding, but reported that only $14 \%$ of the women falling into this same infertility category possessed sperm-agglutinins in their serum. They concluded that there was only a "tendency ... towards correlation between presence of spermagglutinins and fertility status".

The antigen chosen to induce infertility has been found to be of prime importance. Although seminal plasma was highly antigenic, Weil \& Roberts (1965) were unable to alter the fertility of rabbits by iso-immunization with seminal plasma. Menge \& Protzman (1967) produced heterologous antiserum in cattle containing sperm-agglutinins against rabbit spermatozoa by injecting rabbit epididymal secretions, seminal plasma, conceptus extracts, or brain tissue. 
However, 'antifertility antibody' was detected only by raising antisera against testis, epididymal spermatozoa or whole semen. In the present experiment, spermatozoa from the vas deferens and epididymis were used both for immunizing and in the immunological assay, thus restricting somewhat the antigenic complexity of the system. Investigations successfully reducing fertility in cattle (Menge, 1967), in guinea-pigs (Isojima, Graham \& Graham, 1959; Katsh, 1959b; Otani et al., 1963) and in rabbits (Behrman \& Nakayama, 1965) have either used testicular antigen or a preparation containing whole spermatozoa. Henle et al. (1938) produced specific heterologous antisera against heads and tails of bull spermatozoa, but there have been no reports of depressed fecundity by iso-immunization with fractions of spermatozoa.

Serum titres as well as litter sizes among systemically immunized mice showed considerable variation between individuals as would be expected from a genetically heterogeneous population. The significant negative regressions of litter size demonstrated that serum titres for both immunological assays reflected the infertility state induced by spermatozoa injections. Edwards (1964), on the other hand, found no correlation between depressed fertility in the mouse and the level of sperm-agglutinins or sperm-immobilizinsin the circulation. McLaren (1966) reported that sperm-agglutination titre could be suppressed or enhanced if the proper adjuvant was employed with spermatozoa, but there was no change in the level of induced infertility. One is led to suspect that spermagglutination titres are detecting both non-specific, sperm-stimulated antibodies as well as antibody responsible for infertility.

A comparison of the two immunological assays showed the sperm-agglutination test to give a higher titre at a given level of fertility. However, the test was time-consuming to operate and although titrations were consistent within one dilution, a degree of subjective interpretation was required to determine the end point. It is well known that non-specific head-to-head agglutination of spermatozoa occurs under a number of natural and experimental conditions. In the titrations reported here, only tail-to-tail agglutination was considered as evidence of specific antibody, but it was recently reported that even this type of agglutination could be simulated by bacteria (Bell, 1968). The passive haemagglutination test was developed for ease of titration and also to ensure the specificity of a particular titration.

The method of coating tannic acid-treated red cells with the 'solubilized' fraction of spermatozoa was judged successful from the standpoint of detecting sperm-antibody, correlating strongly with sperm-agglutinins and detecting titres that were associated with infertility. It was not known precisely if the haemagglutination test was measuring entirely the same antibody as the spermagglutination test, but it appeared that at least some antibodies were common to both. The significant regression of number of offspring with haemagglutination titre suggests that the 'solubilized' fraction of spermatozoa may contain the antigens responsible for inducing sterility.

\section{AGKNOWLEDGMENTS}

I am indebted to Dr Anne McLaren for supervision of the investigation, aid in the statistical analyses, continued encouragement and criticism of the manu- 
script. I also thank Mr Rennie and Mr Keir of Moredon Institute for supplying fresh sheep's blood. This investigation was supported by a Public Health Service Fellowship (No. 5-F2-HD, 823-03) from the National Institute of Child Health and Human Development.

\section{REFERENCES}

Bemrman, S.J. \& Nakayama, M. (1965) Antitestis antibody: its inhibition of pregnancy. Fert. Steril. 16, 37.

Behrman, S. J. \& Otani, Y. (1963) Transvaginal immunization of the guinea pig with homologous testis and epididymal sperm. Int. F. Fert. 8, 829.

BELl, E. B. (1968) An immune-type agglutination of mouse spermatozoa by Pseudomonas maltophilia. 7. Reprod. Fert. 17, 275.

BELL, E. B. \& Wolf, B. (1967) Antibody synthesis in vitro by the rabbit vagina against diphtheria toxoid. Nature, Lond. 214, 423.

BoYDEN, S. V. (1951) The adsorption of proteins on erythrocytes treated with tannic acid and subsequent hemagglutination by antiprotein sera. F. exp. Med. 93, 107.

Dixon, W. J. \& Mood, A. M. (1946) The statistical sign test. F. Am. Statist. Ass. 41, 557.

EDWARDs, R. G. (1960a) Complement-fixing activity of normal rabbit serum with rabbit spermatozoa and seminal plasma. F. Reprod. Fert. 1, 268.

EDWARDs, R. G. (1960b) Antigenicity of rabbit semen, bull semen and egg yolk after intravaginal or intramuscular injection of female rabbits. F. Reprod. Fert. 1, 385.

EDWARDs, R. G. (1964) Immunological control of fertility in female mice. Nature, Lond. 203, 50.

Eiseman, C. \& Friedman, M. H. (1929) Isospermotoxin. Am. 7. Physiol. 90, 99.

Frankin, R. R. \& Dukes, C. D. (1964) Antispermatozoal antibody in unexplained infertility. Am. 7 . Obstet. Gynec. 89, 6.

Henle, W. \& Henle, G. (1940) Spermatozoal antibodies and fertility: II. Attempt to induce temporary sterility in female guinea pigs by active immunization against spermatozoa. F. Immun. 38, 105.

Henle, W., Henle, G. \& Chambers, L. A. (1938) Studies on the antigenic structure of some mammalian spermatozoa. F. $\exp$. Med. 68, 335.

Henle, W., Henle, G., Church, C. F. \& Foster, C. (1940) Spermatozoal antibodies and fertility: I. Attempt to induce temporary sterility in female white mice by passive immunization with spermatozoal antisera. F. Immun. 38, 97.

Isojima, S. \& AshitakA, Y. (1964) Absorption of sperm antigen from the vagina in guinea pigs. Am. $\mathcal{F}$. Obstet. Gynec. 88, 433.

Isojma, S., Graham, R. M. \& Graham, J. B. (1959) Sterility in female guinea pigs induced by injection with testis. Science, 129, 44.

KATsh, S. (1959a) Immunology, fertility and infertility: A historical survey. Am. 7. Obstet. Gynec. 77, 946.

KATsh, S. (1959b) Infertility in female guinea pigs induced by injection of homologous sperm. Am. $\mathcal{J}$. Obstet. Gynec. 78, 276.

McCartney, J. L. (1923) Further observations on the antigenic effects of semen: mechanism of sterilization of female rats from injections of spermatozoa. Am. J. Physiol. 66, 404.

MaLaren, A. (1964) Immunological control of fertility in female mice. Nature, Lond. 201, 582.

McLaren, A. (1966) Studies on the isoimmunization of mice with spermatozoa. Fert. Steril. 17, 492.

MENGE, A. C. (1967) Induced infertility in cattle by iso-immunization with semen and testis. $\mathcal{F}$. Reprod. Fert. 13, 445.

Menge, A. C. \& Protzman, W. P. (1967) Origin of the antigens in rabbit semen which induce antifertility antibodies. F. Reprod. Fert. 13, 31 .

Otani, Y., Behrman, S. J., Porter, C. W. \& Nakayama, M. (1963) Reduction of fertility in immune guinea pigs. Int. F. Fert. 8, 835.

Parsons, E. I. \& HYde, R. R. (1940) An evaluation of spermatotoxic sera in the prevention of pregnancy. Am. F. Hyg. 31, 89.

Pommerenke, W. T. (1928) Effects of sperm injection into female rabbits. Physiol. Zoöl. 1, 97.

Savinx, E. \& Savini-Castano, Th. (1911) Immunité spermotoxique et fécondation. C. r. Séanc. Soc. Biol. 71, 22.

Sмrth, A. U. (1949) Some antigenic properties of mammalian spermatozoa. Proc. R. Soc. B, 136, 46.

SNELL, G. D. \& Poucher, H. (1943) Relation of number of injections to the titer of sperm iso-agglutinins in mice. Proc. Soc. exp. Biol. Med. 54, 261.

Stavitsky, A. B. (1954) Micromethods for the study of proteins and antibodies. I. Procedure and 
general applications of hemagglutination and hemagglutination inhibition reactions with tannic acid and protein-treated red blood cells. F. Immun. 72, 360 .

Tyler, A. (1961) Approaches to control of fertility based on immunological phenomena. F. Reprod. Fert. $2,473$.

Tyler, A. \& Bishop, D. W. (1963) Immunological phenomena. In: Mechanisms Concerned with Conception, p. 432. Ed. C. G. Hartman. Pergamon Press, Oxford.

Tyler, A., Tyler, E. T. \& Denny, P. C. (1967) Concepts and experiments in immuno-reproduction. Fert. Steril. 18, 153.

WEIL, A. J. (1960) Immunological differentiation of epididymal and seminal spermatozoa of the rabbit. Science, 131, 1040.

WerL, A. J. \& RoBerts, C. O. (1965) Fertility of female rabbits after isoimmunization with seminal plasma. Fert. Steril. 16, 356.

WiLlson, J. T. \& Katsh, S. (1965) Cyto-immunological studies of guinea pig sperm antigens. I. Testicular versus epididymal spermatozoa. Z. Zellforsch. $65,16$. 